\title{
PROFIL MISKONSEPSI YANG TERJADI PADA PESERTA DIDIK DALAM MATERI KALOR DAN PERPINDAHANNYA
}

\author{
Mutia Hariza Lubis ${ }^{\text {a) }}$, Ika Mustika Sari ${ }^{\text {b) }}$, Parlindungan Sinaga ${ }^{\text {c) }}$ \\ Program Studi Pendidikan Fisika, Universitas Pendidikan Indonesia, Jl. Dr. Setiabudhi 229, Bandung 40154, \\ Indonesia \\ Email: a) mutia.hariza@student.upi.edu , b) 1 kams@upi.edu,${ }^{c}$ psinaga@upi.edu
}

\begin{abstract}
Abstrak
Fisika adalah bagian dari sains yang mempelajari berbagai konsep pada objek makroskopis maupun mikroskopis yang tidak semuanya dapat diamati secara langsung, salah satunya pada materi kalor dan perpindahannya. Hal ini menjadi salah satu faktor yang mempengaruhi tingkat pemahaman peserta didik, sejalan dengan aspek pengetahuan fisika yang mengacu pada pemahaman konsep (Depdiknas, 2006) [1]. Tujuan dari penelitian yang dilakukan ialah mengidentifikasi miskonsepsi yang terjadi pada peserta didik dalam materi Kalor dan Perpindahannya. Metode yang digunakan dalam penelitian ialah deskriptif kualitatif melalui tes pemahaman konsep berbentuk three-tier. Subjek pada penelitian ini ialah peserta didik kelas XI SMA yang berjumlah 37 orang. Hasil dari penelitian yang dilakukan menunjukkan bahwa 54,95\% mengalami miskonsepsi sedangkan sisanya $15,92 \%$ tidak paham konsep, 20,42\% tidak tahu konsep, 2,40\% paham parsial, dan 6,31\% paham. Oleh karena itu, dapat disimpulkan bahwa adanya miskonsepsi yang terjadi pada peserta didik dalam materi kalor dan perpindahannya. Implikasi dari penelitian ini diperlukan suatu tindakan yang mampu meminimalisir miskonsepsi peserta didik pada materi Kalor dan Perpindahannya.
\end{abstract}

Kata-kata kunci: Profil Miskonsepsi; Miskonsepsi; Three-Tier; Kalor dan Perpindahannya.

\begin{abstract}
Physics is a part of science that studies various concepts in macroscopic and microscopic objects that not all can be observed directly. One of them in heat and how their transferred topic. This is one of the factors that influence the level of understanding of students, in line with aspects of knowledge of physics that refers to understanding concepts (Ministry of National Education, 2006) [1]. This study aims to identify misconceptions that occur in students in the topic of heat and how their transferred. The method used in this research is descriptive analysis through concept understanding tests. The results of this research showed that $54.95 \%$ of students experienced misconceptions, while $15,92 \%$ of students did not understand the concept, $20,42 \%$ of students did not know the concept, $2,40 \%$ of students understood partially, and 6,31\% understood. Therefore, it can be concluded that there are misconceptions that occur in students in the heat material and their transferred. The implications of this research require an action that is able to minimize students' misconceptions in the topic of heat and how their transferred .
\end{abstract}

Keywords: Misconception Profile; Misconception; Three-Tier; Heat and Temperature. 


\section{PENDAHULUAN}

Fisika merupakan salah satu mata pelajaran yang diajarkan di jenjang pendidikan Sekolah Menengah Atas (SMA) yang mampu melatih kemampuan berpikir peserta didik. Hal ini dikarenakan fisika adalah bagian dari sains yang mempelajari tentang fenomena dan gejala alam secara empiris, logis, sistematis, dan rasional yang melibatkan proses dan sikap ilmiah. Fenomena atau gejala yang dipelajari mencakup objek yang observable dan non-observable. Karena keterbatasan kemampuan indra penglihatan, sulit untuk mengamati secara langsung objek-objek yang non-observable. Hal ini menjadi salah satu faktor yang mempengaruhi tingkat pemahaman konsep peserta didik dalam mempelajari fenomena maupun gejala fisika. Pemahaman konsep sangatlah penting dalam pembelajaran fisika, karena dapat mempengaruhi hasil belajar peserta didik di sekolah. Hal ini berkaitan dengan tujuan pembelajaran fisika yaitu untuk menguasai konsep-konsep fisika dan mampu menggunakan metode ilmiah yang dilandasi sikap ilmiah untuk memecahkan permasalahan dalam kehidupan sehari-hari. Sejalan dengan aspek pengetahuan fisika yang mengacu pada pemahaman konsep (Depdiknas, 2006) [1].

Pembelajaran fisika sangat erat kaitannya dengan fenomena dan aplikasinya dalam kehidupan sehari-hari. Pada pembelajaran fisika diperlukan lebih banyak pemahaman daripada penghafalan, maka kunci sukses dalam belajar fisika adalah kemampuan menggunakan tiga hal pokok fisika yaitu, konsep, hukum-hukum atau asas-asas, dan teori-teori (Sakti, 2012) [2]. Salah satu konsep fisika yang dipelajari di Sekolah Menengah Atas (SMA) ialah kalor dan perpindahannya. Pada materi kalor dan perpindahannya sering terjadi kesalahan konsep.

Kesalahan konsep yang masuk ke dalam substruktur kognitif siswa atau yang biasa dikenal dengan miskonsepsi. Menurut Fowler (Suparno, 2005) miskonsepsi merupakan pengertian yang tidak akurat akan konsep, penggunaan konsep yang salah, klasifikasi contoh-contoh yang salah, kekacauan konsep-konsep yang berbeda, dan hubungan hierarkis konsep-konsep yang tidak benar [3]. Miskonsepsi yang sering terjadi pada materi kalor dan perpindahannya terlihat pada penelitian yang dilakukan oleh Pathare dan Pradhan (2010) yang menemukan bahwa adanya miskonsepsi pada materi tekanan, kalor, suhu, dan perpindahan kalor, yaitu konduksi, konveksi dan radiasi, dan tentang teori kinetik dasar [4]. Sozbilir dalam Mahmudah (2013) menyatakan bahwa pada saat es batu mencair, banyak siswa yang beranggapan bahwa suhu es batu berubah, sedangkan konsep yang benar adalah suhu es tidak berubah namun yang menyebabkan es mencair karena adanya kalor laten [5]. Penelitian yang dilakukan oleh Yolanda, dkk (2015), juga mengungkap dari data yang diperoleh menggunakan instrumen Thermal and Transport Concept Inventory (TTCI) yang dilengkapi Certainty of Response Index (CRI) dan wawancara ialah 54,72\% peserta didik mengalami miskonsepsi dan hanya 45,28\% peserta didik paham konsep [6]. Dikutip dari penelitian yang dilakukan oleh Pathare dan Pradhan , penelitian-penelitian jauh sebelumnya ada yang menyatakan beberapa kemungkinan penyebab umum terjadinya miskonsepsi ialah ide yang diduga, bahasa dan metafora, kesulitan konseptual, dan guru yang kurang mampu menjelaskan suatu konsep [4]. Hammer (Pesman \& Eryilmaz, 2010) melaporkan bahwa miskonsepi berdampak pada pemahaman siswa terkait konsep ilmu pengetahuan dan harus diatasi agar peserta didik belajar konsepsi ilmu pengetahuan secara efektif [7]. Untuk mengatasi hal tersebut, perlu adanya kajian profil miskonsepsi pada materi kalor dan perpindahannya.

\section{METODOLOGI}

Penelitian ini menggunakan metode deskriptif kualitatif. Teknik pengambilan sampel pada penelitian ini menggunakan purposive sampling. Subjek penelitian dilakukan pada 37 orang peserta didik kelas XI yang telah mempelajari materi kalor dan perpindahannya di salah satu SMA Negeri Bandung. Teknik pengumpulan data pada penelitian ini menggunakan instrumen berupa tes pilihan ganda three-tier. Tes dilakukan untuk mengidentifikasi miskonsepsi yang terjadi pada peserta didik yang menjadi acuan ketika merancang penelitian untuk meminimalisir miskonsepsi pada materi kalor dan perpindahannya. Hasil dari tes yang dilakukan, kemudian dikategorikan berdasarkan yaitu [8], 
TABEL 1. Kategorisasi Tingkat Pemahaman Siswa berdasarkan Pola Jawaban

\begin{tabular}{|c|c|c|c|}
\hline Tingkat Pemahaman & $\begin{array}{c}\text { Pola } \\
\text { Jawaban }\end{array}$ & Keterangan & $\begin{array}{l}\text { S } \\
\text { kor }\end{array}$ \\
\hline $\begin{array}{c}\text { Paham } / \\
\text { Understanding }(\mathrm{SU})\end{array}$ & B-Y-b & $\begin{array}{l}\text { Siswa memiliki pemahaman mengenai konsep, yakni } \\
\text { dengan kebenaran konsep yang dimilikinya serta mampu } \\
\text { mengaitkan dengan konsep penunjang }\end{array}$ & 4 \\
\hline $\begin{array}{l}\text { Paham Parsial / Partial } \\
\text { Understanding (PU) }\end{array}$ & B-T-b & $\begin{array}{l}\text { Siswa memiliki pemahaman konsep dan alasan yang } \\
\text { tepat tetapi tidak yakin dengan kebenaran konsep yang } \\
\text { dimilikinya }\end{array}$ & 3 \\
\hline $\begin{array}{l}\text { Tidak Tahu / No } \\
\text { Understanding (NU) }\end{array}$ & $\begin{array}{l}\text { B-M-b } \\
\text { B-M-s } \\
\text { S-M-b } \\
\text { S-M-s } \\
\text { S-T-b } \\
\text { S-T-s }\end{array}$ & $\begin{array}{l}\text { Siswa memiliki pengetahuan tentang konsep yang } \\
\text { tepat, siswa tidak yakin dengan konsep yang dimilikinya } \\
\text { bahkan menebak jawaban }\end{array}$ & 2 \\
\hline $\begin{array}{l}\text { Tidak Paham / Partial } \\
\text { Understanding with Spesific } \\
\text { Misconceptions (PUSM) }\end{array}$ & $\begin{array}{l}\text { B-Y-s } \\
\text { B-T-s }\end{array}$ & $\begin{array}{l}\text { Siswa memiliki pengetahuan tentang suatu konsep serta } \\
\text { yakin dengan kebenaran konsep yang dimilikinya, namun } \\
\text { tidak memiliki pemahaman yang kuat ditandai degnan } \\
\text { kesalahan atau miskonsepsi yang tertera pada alasan } \\
\text { penunjang }\end{array}$ & 1 \\
\hline $\begin{array}{l}\text { Miskonsepsi / Spesific } \\
\text { Misconceptions (SM) }\end{array}$ & $\begin{array}{l}\text { S-Y-b } \\
\text { S-Y-s }\end{array}$ & $\begin{array}{l}\text { Siswa menunjukkan pemahaman yang salah mengenai } \\
\text { suatu konsep }\end{array}$ & 0 \\
\hline
\end{tabular}

Keterangan :

Simbol jawaban

B : benar pada opsi jawaban

$\mathrm{S}$ : salah pada opsi jawaban

Simbol alasan

$\mathrm{b}$ : benar pada opsi alasan

s : salah pada opsi alasan

Simbol tingkat keyakinan jawaban

Y: yakin

T: tidak yakin

\section{HASIL DAN PEMBAHASAN}

Dari tes pemahaman konsep berupa three tier terhadap 37 orang siswa yang menjadi subjek penelitian, secara umum hasilnya sebagai berikut:

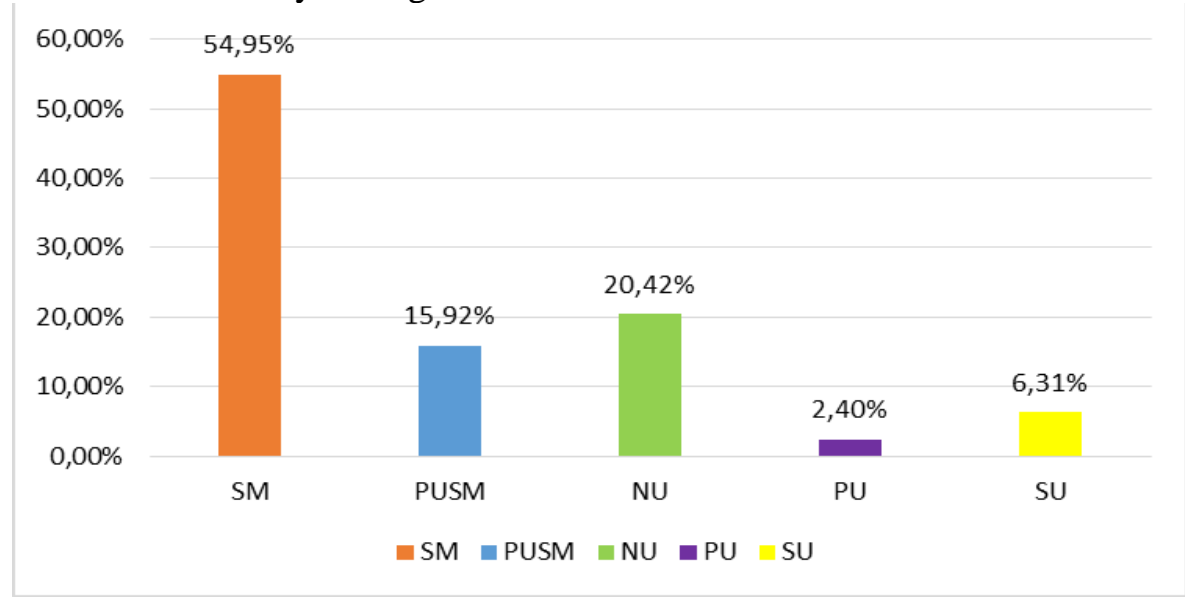




\section{GAMBAR 1. TINGKAT PEMAHAMAN KONSEP}

Keterangan

SU : Sound Understanding / Paham

PU : Partial Understanding / Paham Parsial

NU : No Understanding / Tidak Tahu

PUSM : Partial Understanding with Spesific Misconceptions / Tidak Paham

SM : Spesific Misconceptions / Miskonsepsi

Secara garis besar siswa mengalami miskonsepsi lebih tinggi dibandingkan siswa yang tidak paham, tidak tahu, paham parsial, dan paham. Tingginya miskonsepsi yang terjadi pada siswa kelas XI ini menunjukkan bahwa peserta didik kurang memahami materi kalor dan perpindahannya. Terdapat 54,95\% peserta didik yang mengalami miskonsepsi, 20,42\% peserta didik tidak tahu, $15,92 \%$ peserta didik tidak paham, 6,31\% peserta didik paham, dan 2,40\% peserta didik mengalami paham parsial.

Tes yang diberikan kepada peserta didik terdiri dari soal nomor 1,2,3,4 mengukur pemahaman konsep peserta didik pada materi suhu, soal nomor 5,6,7 mengukur pemahaman konsep peserta didik pada materi kalor, dan soal nomor 8 dan 9 mengukur pemahaman konsep peserta didik pada materi perpindahan kalor.

Dari tes berupa three-tier yang diberikan, maka dapat tingkat pemahaman konsep peserta didik dapat dikelompokkan setiap butir soalnya sebagai berikut.

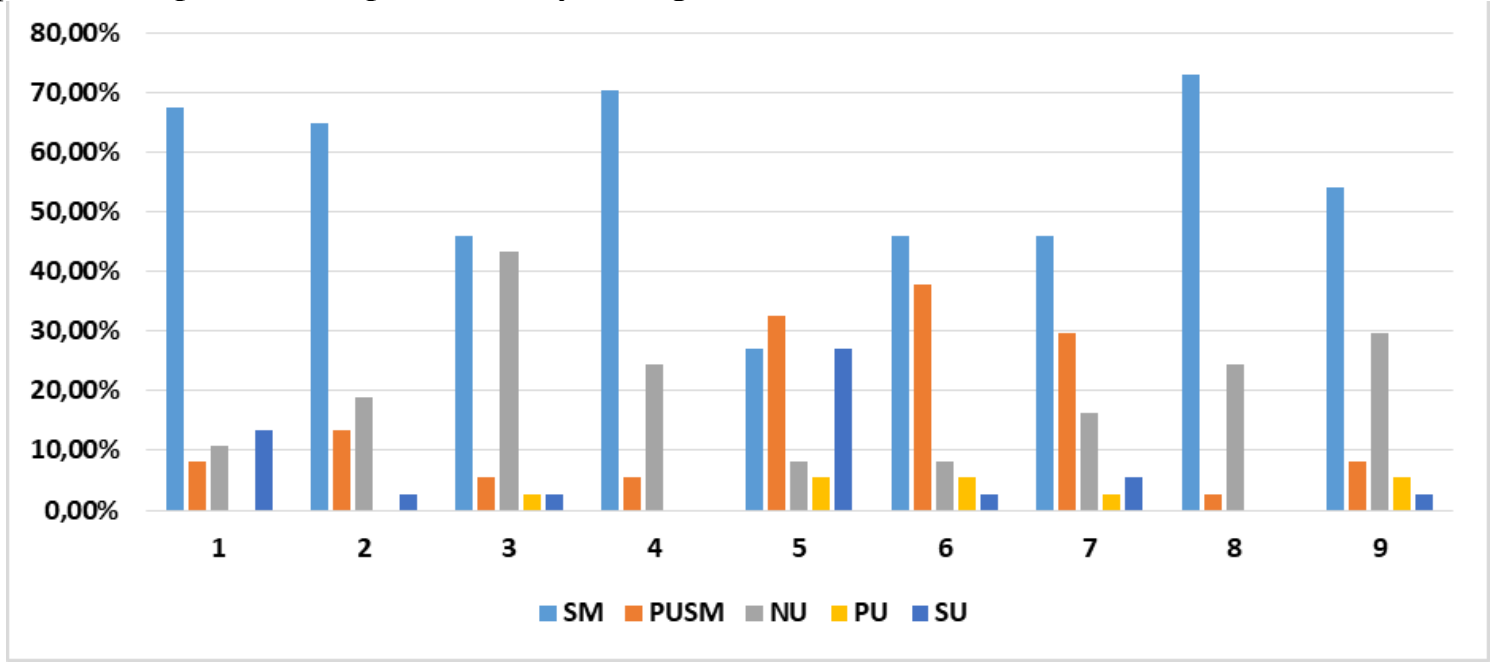

\section{GAMBAR 2. TINGKAT PEMAHAMAN KONSEP TIAP BUTIR SOAL}

Dari grafik diatas diketahui bahwa rata-rata peserta didik mengalami miskonsepsi paling tinggi dibandingkan paham, paham parsial, tidak tahu, dan tidak paham. Terdapat pengecualian pada nomor 5, yaitu lebih banyak peserta didik yang tidak paham dibandingkan dengan miskonsepsi. Miskonsepsi terbesar terjadi pada nomor $8(72,97 \%)$ dibandingkan dengan nomor $4(70,27 \%)$, nomor $1(67,57 \%)$, nomor $2(64,86 \%)$, nomor $9(54,05 \%)$, nomor 3,6,7 (45,95\%), dan nomor $5(27,03 \%)$.

Peserta didik yang tidak paham persentase terbesarnya terdapat pada nomor $6(37,84 \%)$ dibandingkan dengan nomor 5 (32,43\%), nomor $7(29,73 \%)$, nomor $2(13,51 \%)$, nomor $1,9(8,11 \%)$, nomor $3,4(5,41 \%)$, dan nomor $8(2,70 \%)$. Peserta didik yang tidak tahu persentase terbesarnya terdapat pada nomor $3(43,24 \%)$ dibandingkan dengan nomor $9(29,73 \%)$, nomor 4,8 $(24,32 \%)$, nomor $2(18,92 \%)$, nomor $7(16,22 \%)$, nomor $1(10,81 \%)$, dan nomor 5,6 (8,11\%). Peserta didik yang mengalami paham parsial persentase terbesarnya terdapat pada nomor 5,6,9 $(5,41 \%)$ dibandingkan dengan nomor 3,7 (2,70\%), dan nomor 1,2,4,8 (0\%). Yang terakhir, persentase terbesar peserta didik yang paham terdapat pada nomor $5(27,03 \%)$ dibandingkan dengan nomor $1(13,51 \%)$, nomor $7(5,41 \%)$, nomor $2,3,6,7(2,70 \%)$, dan nomor $4,8(0 \%)$. 
Tingginya miskonsepsi yang terjadi pada peserta didik dalam bahasan kalor dan perpindahannya terjadi akibat proses pembelajaran yang kurang membangun pemahaman konsep peserta didik. Melalui observasi dan wawancara yang dilakukan, kegiatan pembelajaran yang terjadi terfokus pada pembahasan soal. Peserta didik pun terbiasa dengan pembelajaran seperti itu. Hal inilah yang menjadi salah satu faktor kurangnya pemahaman konsep peserta didik. Kurangnya pemahaman konsep dikhawatirkan akan menyebabkan rambatan miskonsepsi. Oleh karena itu, sangat disayangkan jika miskonsepsi tidak segera ditindak lanjuti. Hasil penelitian ini diharapkan memberikan informasi mengenai tingkat pemahaman konsep peserta didik pada materi kalor dan perpindahannya, sehingga guru bisa memilih strategi pembelajaran yang tepat untuk meminimalisir terjadinya miskonsepsi.

\section{SIMPULAN}

Berdasarkan data dan hasil pembahasan diperoleh kesimpulan bahwa profil miskonsepsi yang terjadi pada peserta didik pada materi kalor dan perpindahannya terlihat dari hasil analisis tes pemahaman konsep berbentuk three-tier. Ada beberapa tingkatan pemahaman peserta didik yang teridentifikasi dari analisis, yaitu 54,95\% peserta didik mengalami miskonsepsi sedangkan sisanya 15,92\% peserta didik tidak paham konsep, $20,42 \%$ peserta didik tidak tahu konsep, 2,40\% peserta didik paham parsial, dan $6,31 \%$ peserta didik paham dengan konsep. Tingginya miskonsepsi yang terjadi pada peserta didik harus ditindak lanjuti, salah satunya guru harus memilih strategi pembelajaran yang tepat dalam pembelajaran kalor dan perpindahannya sebagai upaya meminimalisir miskonsepsi yang terjadi pada peserta didik.

\section{REFERENSI}

[1] Depdiknas .2006. Permendiknas No 22 Tahun 2006 Tentang Standar Isi. Jakarta : Depdiknas.

[2] Sakti, I., Puspasari, Y. M., \& Risdianto, E. (2012). Pengaruh Model Pembelajaran Langsung (Direct Instruction) Melalui Media Animasi Berbasis Macromedia Flash Terhadap Minat Belajar Dan Pemahaman Konsep Fisika Siswa Di SMA Plus Negeri 7 Kota Bengkulu. In Exacta. 10(_): 1- 10.

[3] Suparno, P. 2005.Miskonsepsi dan Perubahan Konsep dalam Pendidikan Fisika. Jakarta: Grasindo.

[4] Pathare, S. R., \& Pradhan, H. C. (2010). Students' misconceptions about heat transfer mechanisms and elementary kinetic theory. PHYSICS EDUCATION, 629-630.

[5] Mahmudah, R. (2013). Identifikasi Miskonsepsi Peserta Didik pada Konsep Suhu dan Kalor dengan Menggunakan Peta Konsep dan Wawancara. Skripsi. Yogyakarta : UIN Sunan Kalijaga

[6] Yolanda, R., Syuhendri, S., \& Andriani, N. (2015). Analisis pemahaman konsep siswa SMA Negeri se-kecamatan Ilir Barat I Palembang pada materi suhu dan kalor dengan instrumen TTCI dan CRI.

[7] Pesman, H., \& Eryilmaz, A. (2010). Development of a Three-Tier Test to Assess Misconceptions about Simple Electric Ciccuits. The Journal of Educational Research, 103(3), 208-222.

[8] Costu, B. (2008). Learning Science through the PDEODE Teaching Strategy: Helping Students Make Sense of Everyday Situations. Eurasia Journal of Mathematics, Science \& Technology Education, 4(1):3-9. 
